\title{
Net Carbon Dioxide Exchange Rates and Predicted Growth Patterns in Alstroemeria 'Jacqueline' at Varying Irradiances, Carbon Dioxide Concentrations, and Air Temperatures
}

\author{
E.D. Leonardos ${ }^{1}$, M.J. Tsujita ${ }^{2}$, and B. Grodzinski ${ }^{2,3}$ \\ Department of Horticultural Science, University of Guelph, Guelph, Ontario N1G 2W1, Canada
}

Additional index words. carbon gain, environment, greenhouses, modeling, photosynthesis, respiration

\begin{abstract}
The influence of irradiance, $\mathrm{CO}_{2}$ concentration, and air temperature on leaf and whole-plant net $\mathrm{C}$ exchange rate (NCER) of Alstroemeria 'Jacqueline' was studied. At ambient $\mathrm{CO}_{2}$, leaf net photosynthesis was maximum at irradiances above $600 \mu \mathrm{mol} \cdot \mathrm{m}^{-2} \cdot \mathrm{s}^{-1}$ photosynthetically active radiation (PAR), while whole-plant NCER required $1200 \mu \mathrm{mol} \cdot \mathrm{m}^{-2} \cdot \mathrm{s}^{-1}$ PAR to be saturated. Leaf and whole-plant NCERs were doubled under $\mathrm{CO}_{2}$ enrichment of 1500 to $2000 \mu \mathrm{C} \mathrm{CO} /$ /liter. Leaf and whole-plant NCERs declined as temperature increased from 20 to $35 \mathrm{C}$. Whereas the optimum temperature range for leaf net photosynthesis was 17 to $23 \mathrm{C}$, whole-plant $\mathrm{NCER}$, even at high light and high $\mathrm{CO}_{2}$, declined above 12C. Dark respiration of leaves and whole plants increased with a $Q_{10}$ of $\approx 2$ at 15 to $35 \mathrm{C}$. In an analysis of day effects, irradiance, $\mathrm{CO}_{2}$ concentration, and temperature contributed $58 \%, 23 \%$, and $14 \%$, respectively, to the total variation in NCER explained by a second-order polynomial model $\left(R^{2}=\mathbf{0 . 8 5}\right)$. Interactions among the factors accounted for $4 \%$ of the variation in day $\mathrm{C}$ assimilation. The potential whole-plant growth rates during varying greenhouse day and night temperature regimes were predicted for short- and long-day scenarios. The data are discussed with the view of designing experiments to test the importance of $\mathrm{C}$ gain in supporting flowering and high yield during routine harvest of Alstroemeria plants under commercial greenhouse conditions.
\end{abstract}

Alstroemeria is an important greenhouse flower crop because of consumer interest, excellent vase life, high wholesale value, high productivity in greenhouses, and low energy requirements for production during winter(Blom and Piott, 1990; Healy and Wilkins, 1982b). Research on Alstroemeria has focused on promoting earlier winter and spring flowering (Healy and Wilkins, 1986a; Healy et al., 1982; Heins and Wilkins, 1976; Lin and Molnar, 1983) and extending harvest during warm growing conditions such as those experienced in the summer (Blom and Piott, 1990; Bridgen and Bartok, 1990; Lin, 1984, 1985). Although it has been suggested that the storage roots may be a primary $\mathrm{C}$ source for growth and subsequent flowering (Heins and Wilkins, 1979; Healy and Wilkins, 1982a), very little research exists on C assimilation (Leonardos et al., 1992a, 1992b) or partitioning in Alstroemeria (Aker and Healy, 1990; Graper and Healy, 1990).

The growth and development of greenhouse crops depends highly on daily $\mathrm{C}$ gain, the balance between daily photosynthesis and respiratory losses (Jiao et al., 1991a; McCree, 1986). Environmental conditions that will increase photosynthetic rates and decrease photorespiration can result in increased whole-plant $\mathrm{C}$ gain, while reduced dark respiration can also increase final yield. Daily $\mathrm{C}$ gain predictions are based primarily on short-term nondestructive whole-plant net $\mathrm{C}$ exchange rate (NCER) measurements obtained when small populations of plants are exposed to varying environmental conditions involving altered irradiance, $\mathrm{CO}_{2}$ concentration, and temperature (Dutton et al., 1988; Jiao et al., 1991ac). However, as we have pointed out previously regarding another

Received for publication 25 Feb. 1994. Accepted for publication 16 May 1994. Data in this paper comprised a portion of a thesis submitted by E.D. Leonardos in fulfilling a MS requirement. We gratefully acknowledge financial support from the Cecil Delworth Foundation, Agriculture Canada, and the Natural Sciences and Engineering Research Council of Canada to M.J.T. and B.G. The cost of publishing this paper was defrayed in part by the payment of page charges. Under postal regulations, this paper therefore must be hereby marked advertisement solely to indicate this fact.

${ }^{1}$ Graduate student.

${ }^{2}$ Professor

${ }^{3}$ To whom reprint requests should be addressed. perennial greenhouse crop Rosa hybrida 'Samantha', daily C gain predictions must be supplemented with full greenhouse canopy experiments in which day and night conditions are manipulated and $\mathrm{C}$ partitioning is assessed with respect to cut-flower yield and quality (Jiao et al., 1991a). The NCERs and growth predictions obtained should be used primarily to reduce the number of permutations required for more upscale and costly greenhouse trials in which crop yield and quality can be assessed properly.

The purpose of this study was to measure leaf and whole-plant NCER in Alstroemeria under darkened (night) and irradiated (day) conditions for using the $\mathrm{CO}_{2}$ exchange data to predict the growth potential of Alstroemeria, a perennial floriculture crop, in a range of environmental conditions that might be experienced in a typical greenhouse.

\section{Materials and Methods}

Plant material and cultural conditions. The crown portion of Alstroemeria 'Jacqueline' plants were divided into smaller propagules of at least one rhizome with an active growing point, a healthy root system, and three young shoots. Single rhizomes were potted in Promix-BX (Les tourbières Premier LTÉE, Rivière du Loup, Que.), in 15-cm (1.75-liter) and 20-cm (3.25-liter) pots for the leaf and the whole-plant studies, respectively. Plants were placed on benches in a glasshouse under natural sunlight, with temperatures set at $15 \pm 3 \mathrm{C}$ day and $12 \pm 2 \mathrm{C}$ night. Nevertheless, temperatures as high as $28 \mathrm{C}$ were occasionally recorded during the summer. A commercial fertilizer solution $(20 \mathrm{~N}-8.7 \mathrm{P}-16.6 \mathrm{~K})$ (Plant Products Co., Bramalea, Ont.), at $300 \mathrm{mg}$ N/liter, was applied during each watering.

Lodging was not a problem and a supporting system was unnecessary since plants were maintained at a height of $80 \mathrm{~cm}$ or less. Weak shoots were thinned when necessary. Whole plants with leaf canopies of $\approx 3.0$ to 4.5 leaf area index (LAI) were randomly selected from the greenhouse and moved to the laboratory to analyze individual leaf and whole-plant gases. Plants were routinely left overnight in the assimilation chambers to avoid 
potential alteration in photosynthesis and $\mathrm{C}$ export associated with mechanical stress (Pappas and Mitchell, 1985; Pickard and Minchin, 1990). Plants used in the leaf studies were grown during the spring and summer, and leaf $\mathrm{CO}_{2}$ exchange measurements were taken during Summer 1991. Plants used in the whole-plant studies were grown during the summer and fall, and whole-plant $\mathrm{CO}_{2}$ exchange measurements were taken during Fall 1992.

Leaf net $\mathrm{CO}_{2}$ exchange measurements. Estimates of steadystate net $\mathrm{CO}_{2}$ exchange of apical, fully expanded leaves on flowering shoots of intact Alstroemeria plants were measured using two open-flow leaf cuvette gas analysis systems described elsewhere (Proctor et al., 1982; Woodrow et al., 1988). The two analysis systems, which differed primarily in the size and design of the leaf cuvettes, provided us with virtually identical estimates of leaf NCER (see Results).

The influence of each environmental factor (irradiance, $\mathrm{CO}_{2}$ concentration, and air temperature) on leaf NCER was evaluated by varying one factor at a time, while the other environmental factors were set at predetermined levels. A minimum of five leaves on five flowering shoots provided the data for a series of measurements at different levels of irradiance, $\mathrm{CO}_{2}$ concentration, or temperature. Each leaf NCER measurement was taken over a 30min period after a steady NCER had been established. Leaf dark respiration rates at different temperatures were measured shortly after turning off the lights.

Whole-plant net $\mathrm{CO}_{2}$ exchange measurements. A whole-plant net $\mathrm{CO}_{2}$ exchange system similar to that described by Dutton et al. (1988) was constructed. The whole-plant gas analysis system, operating in semiclosed mode, consisted of four clear acrylic (plexiglass) plant holding chambers. Each chamber measured $82 \times 52 \times 45 \mathrm{~cm}$. The system was totally computerized with the capacity to control and analyze the environment of each chamber separately. Highpressure sodium (HPS) lamps (1000 W) (Lumalux LU1000; GTE Sylvania Canada Limited, Drummondville, Que.) provided maximum photosynthetically active radiation (PAR) $(400$ to $700 \mathrm{~nm})$ of $2000 \mu \mathrm{mol} \cdot \mathrm{m}^{-2} \cdot \mathrm{s}^{-1}$, as measured by quantum sensors (Q3991-4; LICOR, Lincoln, Neb.) placed at the top of the plant canopy.

Temperature and humidity were controlled continuously and independently by specially designed compartments attached to each chamber. Each of these compartments included a circulating fan and two heat exchangers (one cooling and one heating radiator). The circulating fan facilitated air movement through the two radiators inside the temperature-humidity compartment and through the plant canopy inside the chamber. Air temperature inside the chamber was measured with a linear thermistor (YSI 44018; Yellow Springs Industrial Co., Yellow Springs, Ohio) and was maintained at 10 to $40 \mathrm{C}( \pm 0.2 \mathrm{C})$ by adjusting the temperature of the cooling and the heating radiators. A transducer(T6000; Fairchild Industrial Products Co., Winston-Salem, N.C.) controlled a mixing valve allowing proportional mixing of cooling solution for the cooling radiator, therefore controlling the temperature of the cooling radiator. A relay regulated the heating capacity of a heater (220100; Temro Division, Bull Canada, Winnipeg, Man.) controlling the temperature of the heating solution for the heating radiator. To avoid heat load from the light source, tempered glass and water heat filters were placed between the lamp and the top of the chamber. Humidity of the air inside the chamber was measured by a humidity transmitter (Dewtrak series; EG\&G, Waltham, Mass.) and maintained at a preset saturation vapor pressure deficit (SVPD) $( \pm 0.3 \mathrm{kPa})$ by setting the temperature of the cooling radiator at the desired level to condense excess moisture.

Carbon dioxide concentration was monitored and adjusted by an infrared gas analyzer (IRGA) (Analytical Development Co.,
Hoddesdon, England), while the chamber was in open mode. A preset $\mathrm{CO}_{2}$ concentration $\left( \pm 10 \mu \mathrm{l} \cdot \mathrm{liter}^{-1}\right)$ was maintained at 300 to $4000 \mu \mathrm{l} \cdot \mathrm{liter}^{-1}$ in each chamber by adding pure $\mathrm{CO}_{2}$ (Canox, Guelph, Ont.) with a mass flow controller (100 standard $\left.\mathrm{cm}^{3} \cdot \mathrm{min}^{-1}\right)$ (MKS Instruments, Nepean, Ont.). Carbon dioxide concentration was adjusted below ambient atmospheric levels using a $\mathrm{CO}_{2}$ scrubber (soda lime 6 to 12 mesh; Fisher Scientific, Toronto, Ont., Canada). While estimating the $\mathrm{CO}_{2}$ exchange rate, the chamber was in semiclosed mode. A second IRGA (LI-6262; LI-COR) monitored the $\mathrm{CO}_{2}$ concentration, and another mass flow controller (30 standard $\mathrm{cm}^{3} \cdot \mathrm{min}^{-1}$ ) (MKS Instruments) injected pure $\mathrm{CO}_{2}$ to compensate for the $\mathrm{CO}_{2}$ depletion due to plant metabolic activity. NCER was calculated from initial and final $\mathrm{CO}_{2}$ concentrations and pure $\mathrm{CO}_{2}$ injection measurements as previously described by Dutton et al. (1988). Carbon dioxide release in the dark was used to determine whole-plant dark respiration.

The influence of irradiance, $\mathrm{CO}_{2}$ concentration, and air temperature on whole-plant NCER were studied by varying one environmental factor at a time, while the other factors were set at predetermined levels. The NCER data obtained from these experiments on the individual effects of irradiance, air temperature, and $\mathrm{CO}_{2}$ concentration on whole-plant net $\mathrm{CO}_{2}$ exchange and those obtained from additional factorial experiments within the threedimensional experimental region defined by ranges for the three factors (see below) were used in a regression analysis to predict whole-plant NCER at various environments. Measurements for each environmental challenge were normally taken over a 1- to 2$\mathrm{h}$ period, during which time a steady whole-plant NCER had been established. In each experiment, the total data were provided by series of measurements on a minimum of four replicates (i.e., plant-chamber combinations) in which LAI was 3.0 to 4.5. LAI was estimated as the ratio of the leaf area of the plants, obtained using a leaf area meter (LI-3000; LI-COR), divided by the area of the chamber's floor. The leaf area measurements were obtained destructively at the end of the daily $\mathrm{CO}_{2}$ exchange measurements.

Whole-plant NCER model. A whole-plant NCER model was developed by fitting the NCER data obtained at the various irradiances ( 0 to $1650 \mu \mathrm{mol} \cdot \mathrm{m}^{-2} \cdot \mathrm{s}^{-1} \mathrm{PAR}$ ), air temperatures (12 to $35 \mathrm{C}$ ), and $\mathrm{CO}_{2}$ concentrations (30 to $2100 \mu \mathrm{l} \cdot$ liter $^{-1}$ ) to the following second-order polynomial function (Jiao et al., 1991a):

$$
\begin{aligned}
& \text { NCER }=\beta_{1}+\beta_{2} \cdot \mathrm{I}+\beta_{3} \cdot \mathrm{T}+\beta_{4} \cdot \mathrm{CO}_{2} \\
& +\beta_{5} \cdot \mathrm{I}^{2}+\beta_{6} \cdot \mathrm{T}^{2}+\beta_{7} \cdot \mathrm{CO}_{2}^{2} \\
& +\beta_{8} \cdot \mathrm{I} \cdot \mathrm{T}+\beta_{9} \cdot \mathrm{I} \cdot \mathrm{CO} \mathrm{O}_{2}+\beta_{10}^{2} \cdot \mathrm{T} \cdot \mathrm{CO}_{2}+\beta_{11} \cdot \mathrm{I} \cdot \mathrm{T} \cdot \mathrm{CO}_{2}
\end{aligned}
$$

where NCER is in $\mu \mathrm{mol} \mathrm{CO}_{2} / \mathrm{m}^{2}$ per sec; I, T, and $\mathrm{CO}_{2}$ are irradiance, air temperature, and $\mathrm{CO}_{2}$ concentration, respectively; and $\beta_{1}$ to $\beta_{11}$ are coefficients.

The coefficients of the model were calculated using SAS's general linear model (GLM) procedures (SAS Institute, 1988). Response surfaces were generated by SAS Graph (SAS Institute, 1988) using the second-order Eq.[1] and the estimates of the coefficients.

Irradiance and $\mathrm{CO}_{2}$ curve fitting. For curve fitting of leaf or whole-plant NCER response data to varying irradiance, a general asymptotic function was used in the form of

$$
\operatorname{NCER}=\gamma_{1} \cdot\left(1-\mathrm{e}^{-\gamma 2 \cdot \mathrm{I}}\right)+\gamma_{3}
$$

where I is irradiance in $\mu \mathrm{mol} \cdot \mathrm{m}^{-2} \cdot \mathrm{s}^{-1} \mathrm{PAR}$; $\mathrm{e}$ is the base of natural logarithms with a value of $\approx 2.718$; and $\gamma_{1}, \gamma_{2}$, and $\gamma_{3}$ are coefficients.

Leaf or whole-plant NCER response data to varying $\mathrm{CO}_{2}$ concentration were fitted to a rectangular hyperbola in the form of 


$$
\mathrm{NCER}=\delta_{1} \cdot \mathrm{CO}_{2} \cdot \mathrm{NCER}_{\max } /\left(\delta_{1} \cdot \mathrm{CO}_{2}+\mathrm{NCER}_{\text {max }}\right)+\delta_{2}
$$

where $\mathrm{CO}_{2}$ concentration is in $\mu 1 \cdot$ liter $^{-1}$; $\mathrm{NCER}_{\max }$ is the maximum NCER at saturating $\mathrm{CO}_{2}$ concentrations; and $\delta_{1}$ and $\delta_{2}$ are coefficients.

Dark respiration response to temperature. The Arrhenius equation (Johnson and Thornley, 1985) was used, as described for roses (Jiao et al., 1991a), to relate leaf or whole-plant dark respiration rates to air temperature:

$$
\mathrm{R} d=\mathrm{A} \cdot \mathrm{e}^{-\mathrm{E} a / \mathrm{R} \cdot \mathrm{T}^{\prime}}
$$

where $\mathrm{R} d$ is the dark respiration rate in $\mu \mathrm{mol} \mathrm{CO} / \mathrm{m}^{2}$ per sec; $\mathrm{A}$ is constant; $\mathrm{e}$ is the base of natural logarithms with a value of 2.718; $\mathrm{Ea}\left(\mathrm{cal} \cdot \mathrm{mol}^{-1}\right)$ is the apparent activation energy of the dark respiration reaction; $\mathrm{R}\left(\mathrm{cal} \cdot \mathrm{mol}^{-1} \cdot \mathrm{K}^{-1}\right)$ is the gas constant with a value of
1.987 ; and $\mathrm{T}^{\prime}\left({ }^{\circ} \mathrm{K}\right)$ is the absolute temperature.

SAS's least squares nonlinear regression (NLIN) procedure (SAS Institute, 1988) was used to estimate the coefficients of Eqs.[2-4].

\section{Results}

Influence of irradiance. At ambient $\mathrm{CO}_{2}$ and $17 \mathrm{C}$, leaf net photosynthesis reached saturation at irradiances above $\approx 600$ $\mu \mathrm{mol} \cdot \mathrm{m}^{-2} \cdot \mathrm{s}^{-1} \mathrm{PAR}$, with a maximum rate of $\approx 10.5 \mu \mathrm{mol} \mathrm{CO}$ fixed/ $\mathrm{m}^{2}$ per sec (Fig. 1). In contrast, whole-plant NCERs at ambient $\mathrm{CO}_{2}$ and $18 \mathrm{C}$ were not saturated until the irradiance level was raised above $1200 \mu \mathrm{mol} \cdot \mathrm{m}^{-2} \cdot \mathrm{s}^{-1}$ PAR. Maximum whole-plant NCERs ( $\approx 5.2 \mu \mathrm{mol} \mathrm{CO} / \mathrm{m}^{2}$ per sec) were only half those observed in the leaves on a leaf area basis.

Linear regression analyses were applied to the leaf and whole-

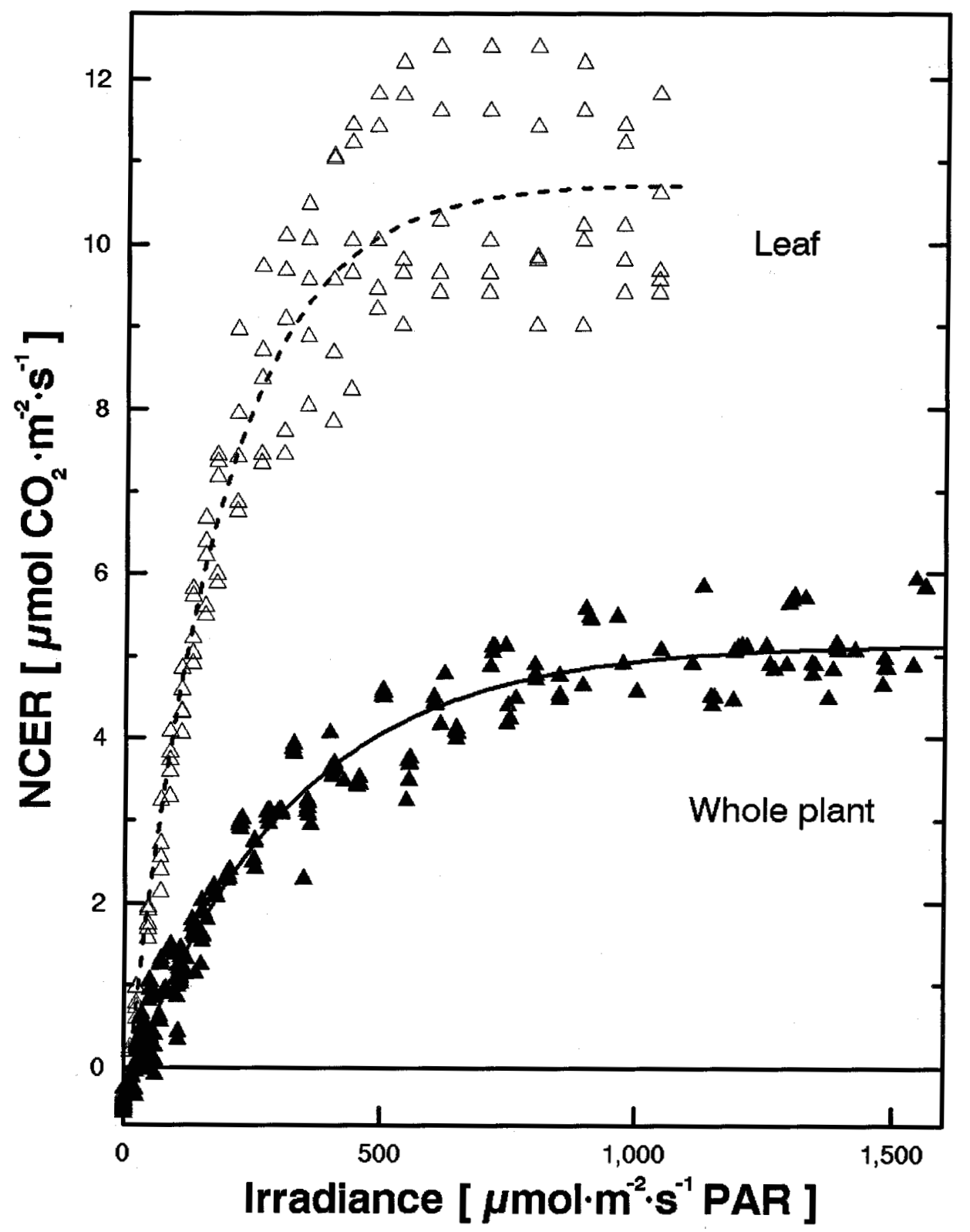

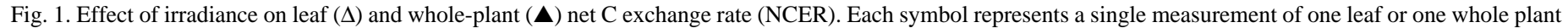

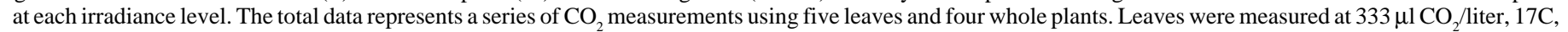

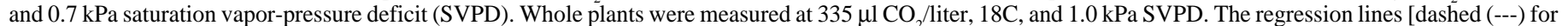
leaves, solid (__ for whole plants] were fitted using the asymptotic Eq.[2]. 
plant NCER measurements at irradiance levels lower than 140 and $100 \mu \mathrm{mol} \cdot \mathrm{m}^{-2} \cdot \mathrm{s}^{-1} \mathrm{PAR}$, respectively (graph not shown). The quantum yield for $\mathrm{CO}_{2}$ uptake, the estimate of the maximum photosynthetic efficiency of radiation energy conversion, was estimated as the slope of the linear regression curve line (Osborne and Garrett, 1983). The quantum yield for the Alstroemeria leaves, based on incident PAR, was $44 \pm 1 \mathrm{mmol} \mathrm{CO} / \mathrm{mol}$ quanta, whereas that for the whole plants was only $19 \pm 2 \mathrm{mmol} \mathrm{CO} / \mathrm{mol}$ quanta. The leaf light compensation point was $\approx 11 \mu \mathrm{mol} \cdot \mathrm{m}^{-2} \cdot \mathrm{s}^{-1} \mathrm{PAR}$, whereas that of the whole plants was $\approx 21 \mu \mathrm{mol} \cdot \mathrm{m}^{-2} \cdot \mathrm{s}^{-1} \mathrm{PAR}$.

Influence of $\mathrm{CO}_{2}$ concentration. The plants used in this study were grown in greenhouses at ambient atmospheric $\mathrm{CO}_{2}$ concentration $\left(\approx 350 \mu 1 \cdot\right.$ liter $\left.^{-1}\right)$. Therefore, the data in Fig. 2 represent only the short-term response of leaves and whole plants to different $\mathrm{CO}_{2}$ levels. Leaf net photosynthesis at $1000 \mu \mathrm{mol} \cdot \mathrm{m}^{-2} \cdot \mathrm{s}^{-1} \mathrm{PAR}$ increased from $\approx 10 \mu \mathrm{mol} \mathrm{CO} / \mathrm{m}^{2}$ per sec at ambient $\mathrm{CO}$ to $\approx 15 \mu \mathrm{mol}$ $\mathrm{CO}_{2} / \mathrm{m}^{2}$ per sec at $\mathrm{CO}_{2}$ levels twice ambient $\left(750 \mu \mathrm{l} \cdot \mathrm{liter}^{-1}\right)$ and to $\approx 18 \mu \mathrm{mol} \mathrm{CO} / \mathrm{m}^{2}$ per sec above $1500 \mu \mathrm{CO}_{2} /$ liter (Fig. 2A). At $1200 \mu \mathrm{mol} \cdot \mathrm{m}^{-2} \cdot \mathrm{s}^{-1} \mathrm{PAR}$, whole-plant NCER was saturated above $1500 \mu \mathrm{l} \mathrm{CO} /$ liter with a maximum of $\approx 9 \mu \mathrm{mol} \mathrm{CO} / \mathrm{m}^{2}$ per sec, which was almost double that observed at ambient $\mathrm{CO}_{2}$ concentration (Fig. 2A). At the lower irradiance level of $200 \mu \mathrm{mol} \cdot \mathrm{m}^{-2} \cdot \mathrm{s}^{-1}$ PAR, typical of cloudy winter growing conditions, whole-plant NCER was saturated at $\approx 700 \mu \mathrm{l} \mathrm{CO}$ /liter. Although $\mathrm{CO}_{2}$ enrichment increased whole-plant NCER at $200 \mu \mathrm{mol} \cdot \mathrm{m}^{-2} \cdot \mathrm{s}^{-1} \mathrm{PAR}$, the increase was only $30 \%$ to $40 \%$ (Fig. 2A). At subambient $\mathrm{CO}_{2}$

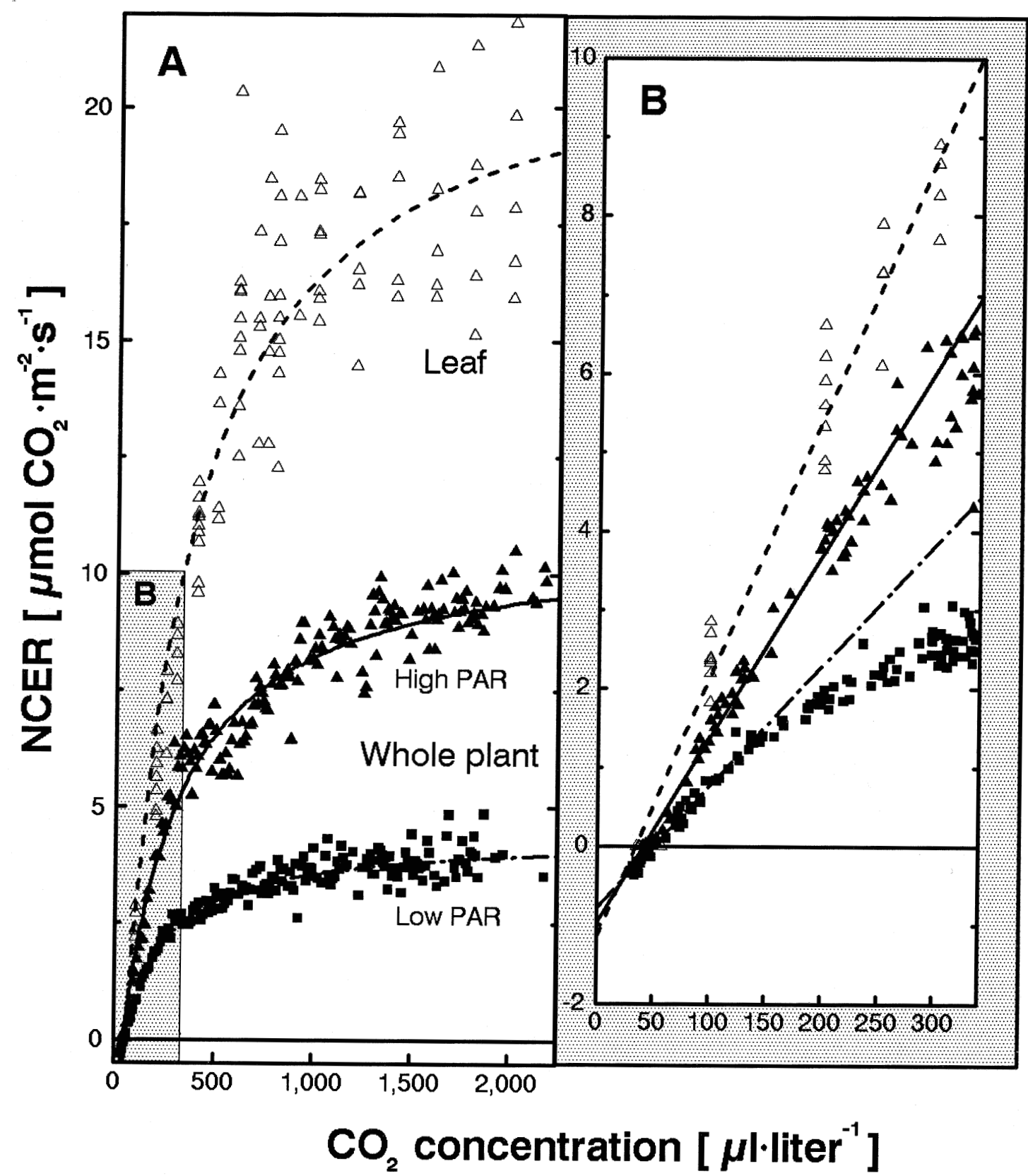

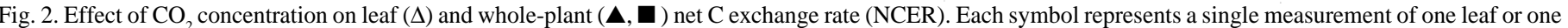

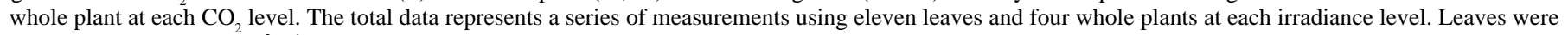
measured at $1000 \mu \mathrm{mol} \cdot \mathrm{m}^{-2} \cdot \mathrm{s}^{-1}$ photosynthetically active radiation (PAR), $18 \mathrm{C}$, and $0.7 \mathrm{kPa}$ saturation vapor-pressure deficit (SVPD). Whole plants were measured

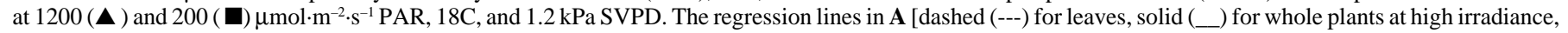
and chain dashed (_ _ - ) for the whole plants at low irradiance] were fitted using Eq.[3]. The shaded area in $\mathbf{A}$, appearing on a larger scale in $\mathbf{B}$, shows NCERs below ambient $\mathrm{CO}_{2}$ concentrations. The linear regression lines in $\mathbf{B}$ were fitted to the linear part of the NCER response curves at subambient $\mathrm{CO}$, levels. 
levels, such as those that can occur during $\mathrm{CO}_{2}$ depletion in tightly sealed greenhouses, leaf and whole-plant NCER were drastically reduced (Fig. 2). The $\mathrm{CO}_{2}$ compensation point of leaves (40 $\mu \mathrm{l}$ $\mathrm{CO}_{2}$ /liter) was similar to that of Alstroemeria whole plants $(50 \mu \mathrm{l}$ $\mathrm{CO}_{2} /$ liter) (Fig. 2B).

Influence of air temperature. Temperature affects photosynthesis and dark respiration of leaves and the respiratory activity of nonfoliar structures. Leaf and whole-plant dark respiration increased exponentially as temperature increased (Fig. 3). The $\mathrm{Q}_{10}$ values for leaves were 1.98 and 1.90 from 15 to $25 \mathrm{C}$ and 25 to $35 \mathrm{C}$, respectively. Whole-plant dark respiration had similar $\mathrm{Q}_{10}$ values of 1.81 at 15 to $25 \mathrm{C}$ and 1.74 at 25 to $35 \mathrm{C}$. Estimates for the coefficients and the apparent activation energies of the Arrhenius Eq. [4] were $\mathrm{A}=1.828 \times 10^{8}$ and $\mathrm{Ea}=11,675 \mathrm{cal} \cdot \mathrm{mol}^{-1}$ for the leaf and $\mathrm{A}=3.666 \times 10^{7}$ and $\mathrm{Ea}=10,141 \mathrm{cal} \cdot \mathrm{mol}^{-1}$ for the whole plant.

The dotted line projected through the shaded area over the entire temperature range (Fig. 3) predicts the magnitude of whole-plant dark respiration at varying temperatures, corrected for $\mathrm{CO}_{2}$ loss from a root-zone mass (i.e., rhizomes, roots, and storage roots) cooled to $12 \mathrm{C}$. The shaded areas (total) in Fig. 3 bordered by the leaf and whole-plant data sets represent the dark respiration of all components of the Alstroemeria plants except the leaves. The

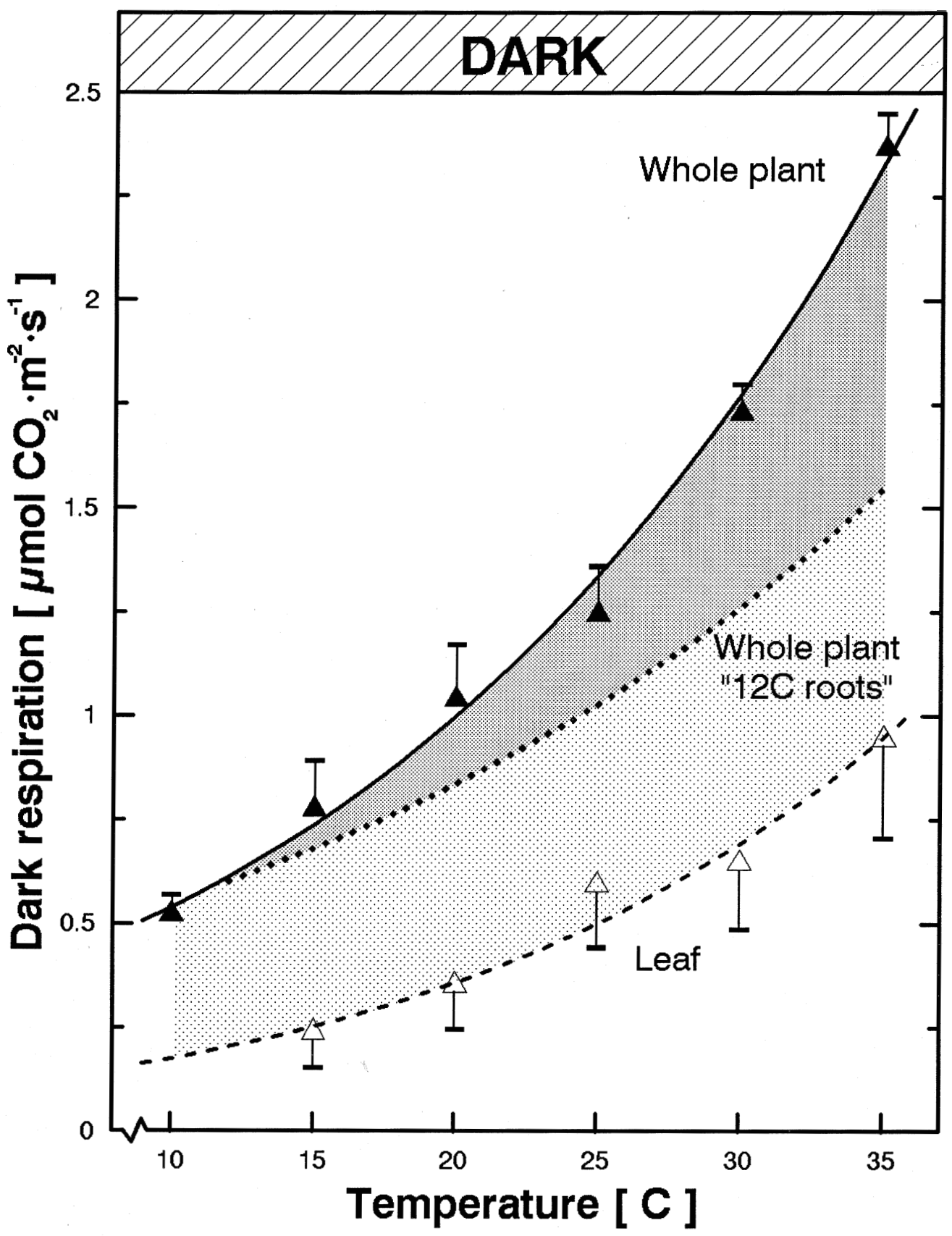

Fig. 3. Effect of air temperature on leaf $(\Delta)$ and whole-plant $(\boldsymbol{\Delta})$ dark respiration at $400 \mu 1 \mathrm{CO}_{2} /$ liter. Thirty leaves (six for each temperature level) were used to provide the leaf data presented. The whole-plant data represents a series of measurements using four whole plants. Symbols represent the means and vertical bars represent the SE. The regression lines through the data points [dashed (---) for leaves, solid (__ for whole plants] were fitted using the Arrhenius Eq.[4]. The shaded areas (total) represent dark respiration of nonfoliar plant tissues at increasing temperatures. The dotted line projected through the shaded areas predicts the dark respiration response of whole plants with roots cooled to 12C, but with their shoots and leaves exposed to air temperatures shown on the $\mathrm{x}$ axis. The difference between the solid line (measured whole-plant rates) and the dotted line (calculated whole-plant rates for plants with cooled roots) predicts the $\mathrm{C}$ savings, due to reduced root respiration, that might be achieved by root cooling (heavily shaded area). 
difference of $0.41 \mu \mathrm{mol} \mathrm{CO}_{2}$ released $/ \mathrm{m}^{2}$ per sec between the whole-plant dark respiration rate of $0.61 \mu \mathrm{mol} \mathrm{CO}$ released $/ \mathrm{m}^{2}$ per sec and the leaf dark respiration rate of $0.20 \mu \mathrm{mol} \mathrm{CO}_{2}$ released/ $\mathrm{m}^{2}$ per sec at $12 \mathrm{C}$ represents predominately the respiration of the root-zone mass. On a dry weight basis, the root-zone mass accounts for $\approx 80 \%$ of the nonfoliar Alstroemeria 'Jacqueline' structures (data not shown).

The data points in Fig. 4 are the NCERs of leaves and whole plants measured over a range of temperature at saturating irradiance and ambient $\mathrm{CO}_{2}$. As the temperature was increased above $25 \mathrm{C}$, SVPD increased from 1.2 to $2.5 \mathrm{kPa}$ at $35 \mathrm{C}$. Gas exchange may have been affected by increasing SVPD at high experimental temperatures (i.e., 30 to $35 \mathrm{C}$ ) but not at temperatures below $25 \mathrm{C}$. Leaf NCERs measured at $25 \mathrm{C}$ were unaffected by changes in SVPD (data not shown). Leaf net photosynthesis has a broad optimal range between 17 and 23C, whereas exposing the whole plant to 20 and $25 \mathrm{C}$ reduces NCER by $20 \%$ and $45 \%$, respectively, relative to the rate observed at $15 \mathrm{C}$ (Fig. 4). A preliminary experiment (data not shown) in which LAI was 1.5 to 2.0 showed that, below $12 \mathrm{C}$, whole-plant NCER was reduced and that, as temperature increased above $15 \mathrm{C}$, whole-plant NCER decreased, as was observed at the higher LAI of 3.0 to 4.5 (Fig. 4).

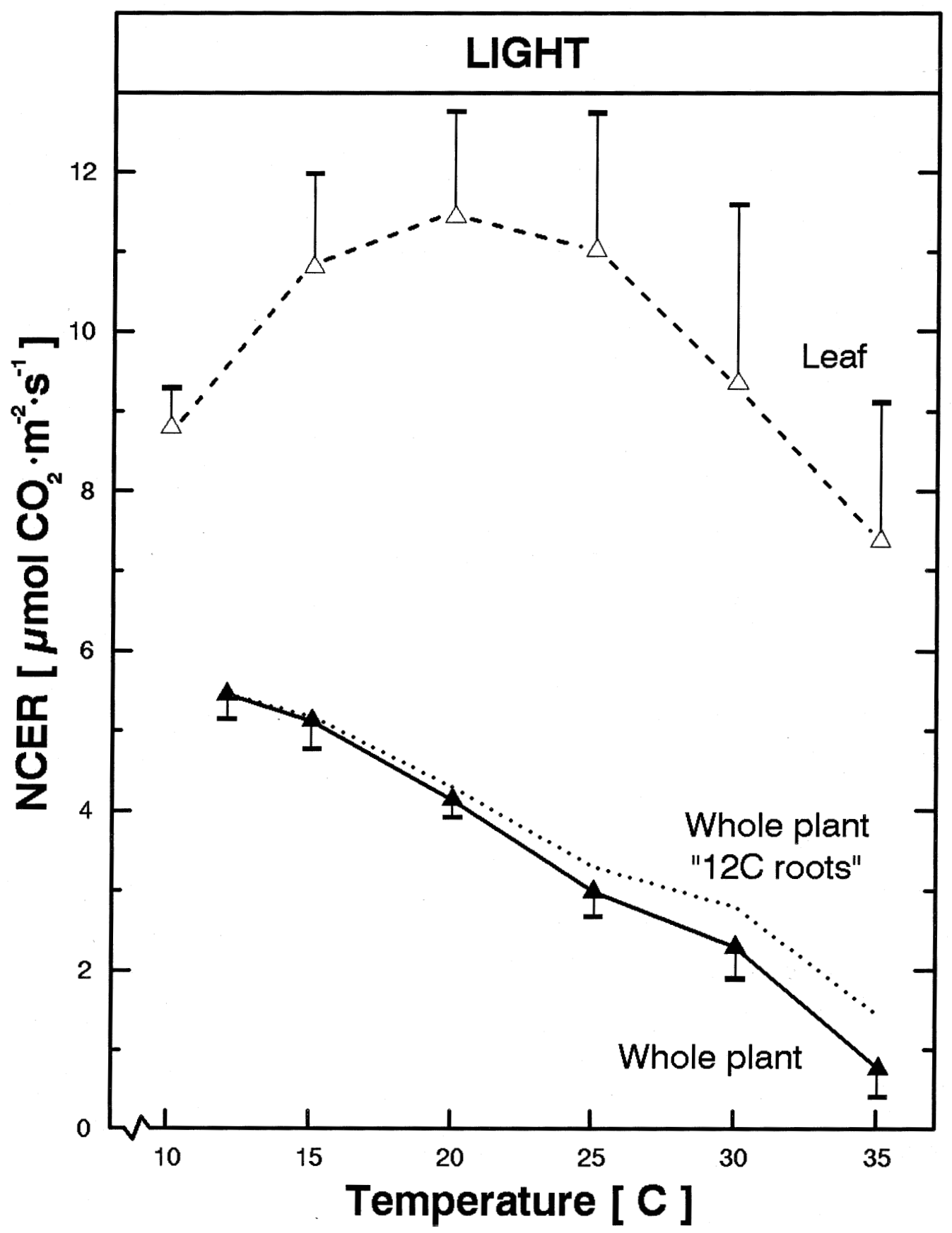

Fig. 4. Effect of air temperature on leaf $(\Delta)$ and whole-plant $(\boldsymbol{\Delta})$ net $C$ exchange rate (NCER). The total data represents a series of measurements using six leaves and four whole plants. Symbols represent the means and vertical bars represent the SE. Leaves were measured at $750 \mu \mathrm{mol} \cdot \mathrm{m}^{-2} \cdot \mathrm{s}^{-1}$ photosynthetically active radiation $(\mathrm{PAR})$ and $333 \mu \mathrm{lCO} /$ /iter. Whole plants were measured at $1200 \mu \mathrm{mol} \cdot \mathrm{m}^{-2} \cdot \mathrm{s}^{-1} \mathrm{PAR}$ and $335 \mu \mathrm{lCO}$ /liter. As temperature increased above $25 \mathrm{C}$, saturation vapor-pressure deficit increased gradually from 1.2 to $2.5 \mathrm{kPa}$ at $35 \mathrm{C}$. The dotted line without symbols predicts the NCER response of whole-plants with their root systems cooled to $12 \mathrm{C}$ (Fig. 3). This dotted line was created from the whole-plant NCERs by adding at each temperature the hypothetical C saving after cooling roots to $12 \mathrm{C}$ to reduce dark respiratory release of $\mathrm{CO}_{2}$ from roots, as shown in Fig. 3. 
Some growers cool the root zone to facilitate vernalization and flowering in Alstroemeria. The dotted line (i.e., without data points) in Fig. 4 represents the expected NCERs of Alstroemeria plants whose roots are cooled to $12 \mathrm{C}$ while the aerial temperature is raised from 12 to $35 \mathrm{C}$. Even though the plants are irradiated, the assumption is that roots are still in the dark and that estimates of root respiration calculated in Fig. 3 can apply here. In spite of reduced $\mathrm{C}$ loss expected from cooled roots, the predicted data (i.e., the dotted line in Fig. 4) show that, when the greenhouse aerial temperature was above $15 \mathrm{C}$, whole-plant day $\mathrm{C}$ gain would still decline significantly.

Because temperature can affect much more than leaf metabolism and because of the problems of assessing the magnitude of mutual shading, whole-plant NCER data sets rather than leaf data sets were used to predict the behavior and growth of Alstroemeria crops as the aerial environment was modified.

Whole-plant NCER model. The analysis of variance of the whole-plant NCER model (Table 1) showed that $85 \%\left(R^{2}=0.85\right)$ of the total experimental variation was explained by the secondorder polynomial function of Eq.[1]. All sources of variation (parameters) in the model were highly significant.

Irradiance (linear and quadratic component) was the most important factor in the model, causing $58.39 \%$ of the variation in NCER accounted by the model. The second most important factor was $\mathrm{CO}_{2}$ concentration (linear and quadratic component) causing $23.49 \%$ of the variation, and third, temperature (linear and quadratic component) with $13.84 \%$. The interaction between irradiance and $\mathrm{CO}_{2}$ concentration was the most important interaction among the three environmental factors, contributing $4.12 \%$ to the model variation. All other interactions accounted for the remaining $0.16 \%$. Estimates of the intercept and parameter coefficients $\left(\beta_{1}\right.$ to $\beta_{11}$ ) of the whole-plant NCER model are shown in Table 1.

Whole-plant NCER response surfaces. A series of whole-plant NCER response surfaces representing six different irradiance levels (Fig. 5) were generated to predict whole-plant NCER at various temperatures and $\mathrm{CO}_{2}$ concentrations. Whole-plant NCER increased with increasing irradiance for all combinations of temperature and $\mathrm{CO}_{2}$ concentration. Temperature had a significant effect on $\mathrm{NCER}$ at all irradiance and $\mathrm{CO}_{2}$ levels. From all response surfaces, it seems that temperatures below $15 \mathrm{C}$ were more favorable for net $\mathrm{C}$ assimilation than temperatures above $15 \mathrm{C}$. Whole- plant NCER decreased as temperature increased. The decrease in whole-plant NCER with increasing temperatures was more critical at low irradiance levels (Fig. $5 \mathrm{a}$ and b), at which negative NCERs were measured. An increase in $\mathrm{CO}_{2}$ concentration at the higher irradiance levels (Fig. $5 \mathrm{~d}-\mathrm{f}$ ) balanced somewhat the negative effect of high temperature on whole-plant NCER. High $\mathrm{CO}_{2}$ levels were more effective at the high (Fig. $5 \mathrm{~d}-\mathrm{f}$ ) than low irradiances (Fig. $5 \mathrm{a}-\mathrm{c}$ ). Furthermore, $\mathrm{CO}_{2}$ enrichment was more efficient at stimulating $\mathrm{CO}_{2}$ fixation between 20 and $25 \mathrm{C}$ at each irradiance level tested.

Predicting daily $C$ gain. The day NCER data outlined in Fig. 5 $\mathrm{b}$ and $\mathrm{e}$ and the night respiration data in Fig. 3 were used to estimate daily growth rates for plants growing under different day and night conditions (Fig. 6). As discussed below, in terms of whole-plant daily $\mathrm{C}$ gain, the length (hours) of the night was generally less important than the length of the day in which photosynthesis occurred (Fig. 6). This concurs with the hourly rate of day $\mathrm{C}$ gain at ambient $\mathrm{CO}_{2}$ and $20 \mathrm{C}$, which was $17 \mathrm{mmol} \mathrm{C} / \mathrm{m}^{2}$ (Fig. 5e), five times greater than the night respiratory $\mathrm{C}$ loss of $3.6 \mathrm{mmol} \mathrm{C} / \mathrm{m}^{2}$ at 20C (Fig. 3). Higher irradiance levels coupled with an extended duration of day irradiation (i.e., long day) and $\mathrm{CO}_{2}$ enrichment had a marked effect on daily $\mathrm{C}$ gain (Fig. 6b). Day temperatures above $15 \mathrm{C}$ reduced daily $\mathrm{C}$ gain significantly, although $\mathrm{CO}_{2}$ enrichment would clearly enhance daily $\mathrm{C}$ gain when day temperatures are raised to $25 \mathrm{C}$.

\section{Discussion}

Day $C$ gain. The whole-plant NCER model (Eq.[1]) provides a means of predicting Alstroemeria growth over a wide range of environmental conditions. Irradiance was clearly the most important variable, accounting for $58 \%$ of the variation in the NCER model. The second most important factor was $\mathrm{CO}_{2}$ concentration, contributing $23 \%$ of the variation. The third variable that significantly altered the potential for day $\mathrm{C}$ accumulation was temperature, which accounted for $14 \%$ of the variance in the predicted NCERs over the range of irradiance (100 to $1500 \mu \mathrm{mol} \cdot \mathrm{m}^{-2} \cdot \mathrm{s}^{-1}$ PAR) and $\mathrm{CO}_{2}$ (100 to $2000 \mu \mathrm{l} \cdot$ liter $^{-1}$ ) levels (Fig. 5). Interactions among these three factors accounted for the remaining $4 \%$ of variation.

In carnation, irradiance and $\mathrm{CO}_{2}$ concentration accounted for

Table 1. Analysis of variance and coefficients of the whole-plant net $\mathrm{C}$ exchange rate (NCER) model. The second-order polynomial function of Eq. [1] $\left(R^{2}=0.849, \mathrm{CV}=26\right)$ was developed by fitting the NCER data obtained at various irradiances ( 0 to $1650 \mu \mathrm{mol} \cdot \mathrm{m}^{-2} \cdot \mathrm{s}^{-1}$ photosynthetically active radiation), air temperatures ( 12 to $35 \mathrm{C}$ ), and $\mathrm{CO}_{2}$ concentrations ( 30 to 2100 $\mu 1 \cdot$ liter $^{-1}$ ). The relative contribution of each component of the model to the total sum of squares (SS) of the model is indicated by the percentage values.

\begin{tabular}{|c|c|c|c|c|c|}
\hline Source & $\mathrm{df}$ & SS & $P>|\mathrm{T}|$ & $\%$ & Coefficient \\
\hline Model & 10 & 17825.93 & 0.0000 & 100.00 & \\
\hline Error & 2471 & 3155.85 & & & \\
\hline Corrected total & 2481 & 20981.78 & & & \\
\hline Intercept & & & & & $\beta_{1}=3.330847827$ \\
\hline I & 1 & 10127.38 & 0.0001 & 56.81 & $\beta_{2}=0.010363474$ \\
\hline $\mathrm{T}$ & 1 & 2447.38 & 0.0001 & 13.73 & $\beta_{3}=-0.356247305$ \\
\hline $\mathrm{CO}_{2}$ & 1 & 3632.81 & 0.0001 & 20.38 & $\beta_{4}=0.007072194$ \\
\hline $\mathrm{I}^{2}$ & 1 & 283.00 & 0.0001 & 1.58 & $\beta_{5}=-0.000004425$ \\
\hline $\mathrm{T}^{2}$ & 1 & 188.74 & 0.0001 & 0.11 & $\beta_{6}=0.005315632$ \\
\hline $\mathrm{CO}_{2}^{2}$ & 1 & 554.79 & 0.0001 & 3.11 & $\beta_{7}=-0.000002602$ \\
\hline $\mathrm{I} \times \mathrm{T}$ & 1 & 0.12 & 0.0001 & $<0.01$ & $\beta_{8}=-0.000093323$ \\
\hline $\mathrm{I} \times \mathrm{CO}_{2}$ & 1 & 734.76 & 0.0012 & 4.12 & $\beta_{9}=0.000000865$ \\
\hline $\mathrm{T} \times \mathrm{CO}_{2}$ & 1 & 0.01 & 0.0001 & $<0.01$ & $\beta_{10}=-0.000062058$ \\
\hline $\mathrm{I} \times \mathrm{T} \times \mathrm{CO}_{2}$ & 1 & 26.92 & 0.0001 & 0.15 & $\beta_{11}=0.000000060$ \\
\hline
\end{tabular}


$82 \%$ and $10 \%$, respectively, of the total variance in the whole-plant net photosynthetic responses, while temperature accounted for only $1 \%$ (Enoch and Sacks, 1978). Using whole-plant NCER rose data, Jiao et al. (1991a) estimated that irradiance, $\mathrm{CO}_{2}$ concentration, and temperature contribute $70 \%, 20 \%$, and $5 \%$, respectively, to the NCER model. Our studies with NCER of whole plants of Alstroemeria 'Jacqueline' clearly show a higher proportional response of day $\mathrm{C}$ assimilation to temperature than was noted for either carnations or roses. As shown in Fig. 4, the leaf data alone tend to underestimate the importance of temperature on wholeplant NCER in Alstroemeria. The root-zone mass comprises $\approx 80 \%$ of the weight of the nonfoliar structures in Alstroemeria 'Jacqueline', but in a simulation in which the root zone was cooled to $12 \mathrm{C}$, whole-plant NCER at elevated temperatures was not altered significantly (Fig. 4). Mutual shading coupled with the increased respiration at elevated aerial temperatures reduces the potential for canopy photosynthesis.

Irradiance. Our studies with leaves and whole plants of

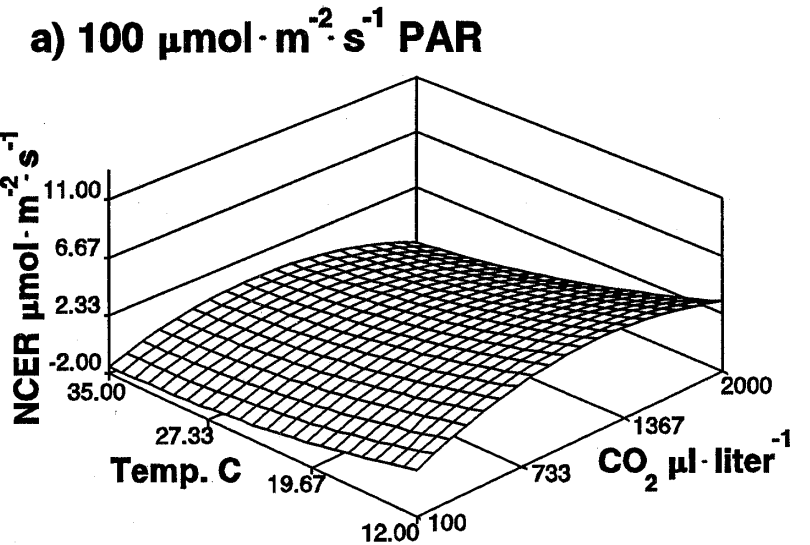

c) $600 \mu \mathrm{mol} \cdot \mathrm{m}^{-2} \cdot \mathrm{s}^{-1}$ PAR

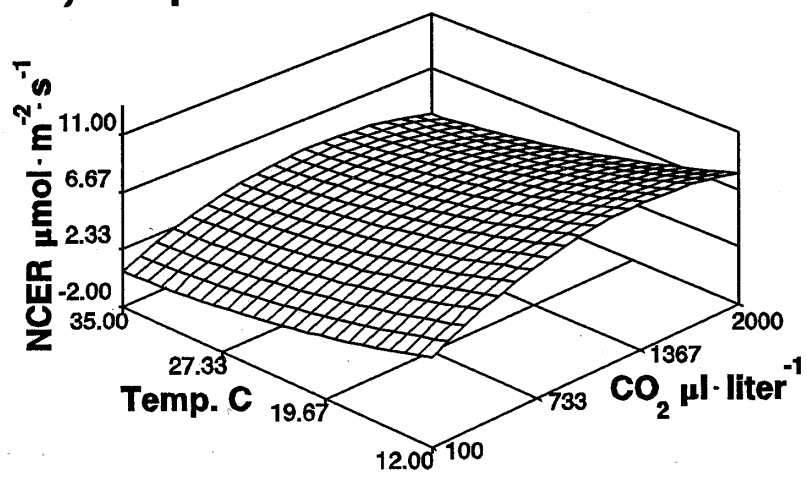

e) $1200 \mu \mathrm{mol} \cdot \mathrm{m}^{-2} \cdot \mathrm{s}^{-1}$ PAR

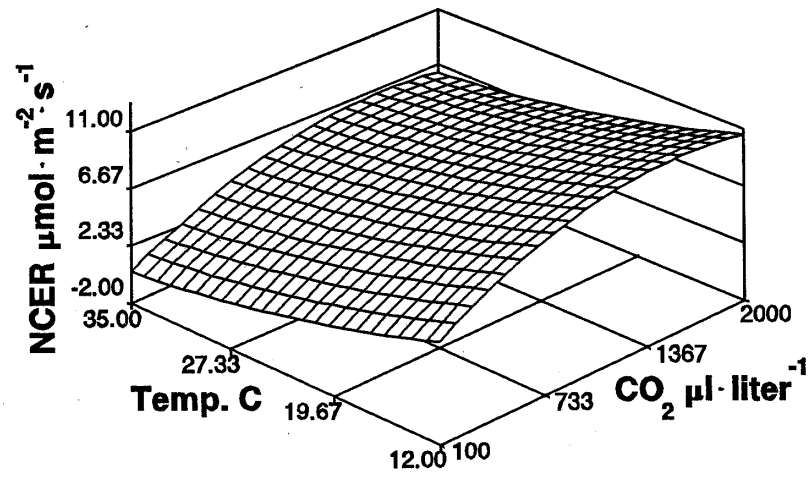

b) $300 \mu \mathrm{mol} \cdot \mathrm{m}^{-2} \cdot \mathrm{s}^{-1}$ PAR
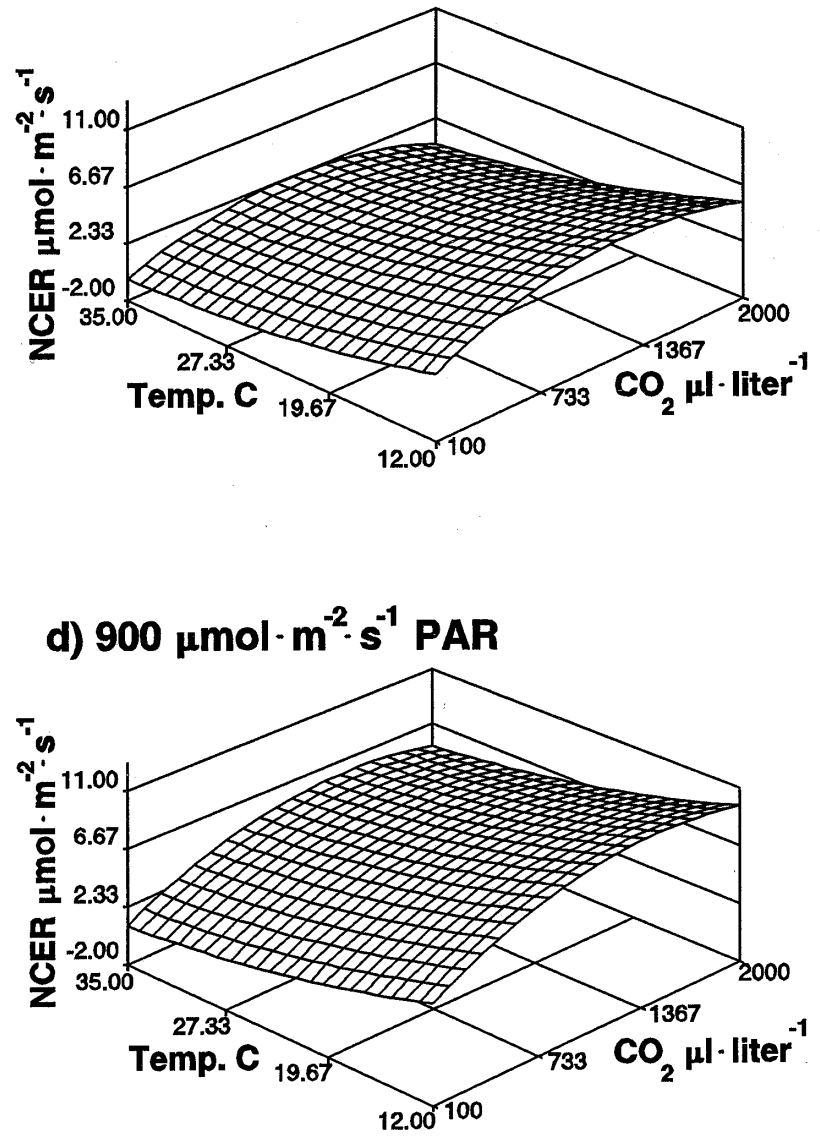

\section{f) $1500 \mu \mathrm{mol} \cdot \mathrm{m}^{-2} \cdot \mathrm{s}^{-1}$ PAR}

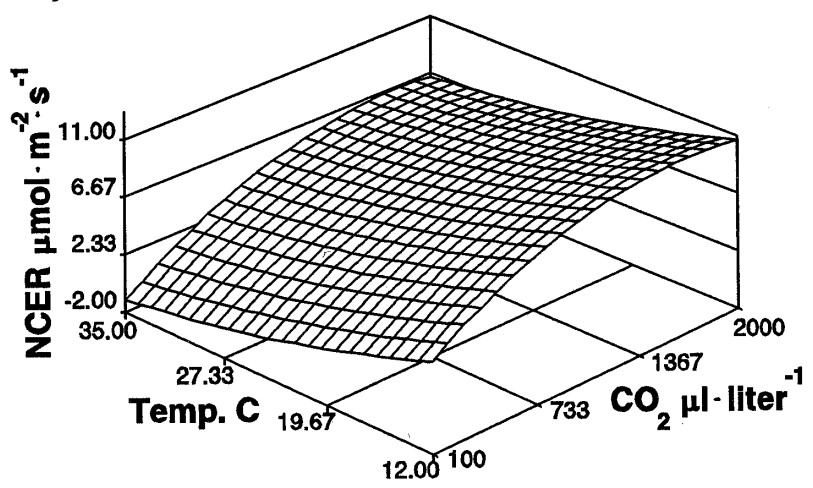

Fig. 5. Response surfaces of whole-plant net $\mathrm{C}$ exchange rate $(\mathrm{NCER})\left(\mu \mathrm{mol} \mathrm{CO} / \mathrm{m}^{2}\right.$ per sec) vs. air temperature $\left({ }^{\circ} \mathrm{C}\right)$ and $\mathrm{CO}_{2}$ concentration $\left(\mu 1 \cdot\right.$ liter $\left.{ }^{-1}\right)$ at different irradiance levels of (a) 100, (b) 300, (c) 600, (d) 900 , (e) 1200 , and (f) $1500 \mu \mathrm{mol} \cdot \mathrm{m}^{-2} \cdot \mathrm{s}^{-1}$ photosynthetically active radiation (PAR). Twenty-four whole plants were used to provide the data used to generate the response surfaces. These response surfaces were generated using the second-order Eq.[1] and the coefficients in Table 1. 
Alstroemeria 'Jacqueline' demonstrate that irradiance level was a predominant factor in regulating photosynthesis in Alstroemeria. Many studies have shown that supplementary lighting with HPS lamps increased flower production in over 15 Alstroemeria cultivars (Blom and Piott, 1991; Euro-Floratech, 1992; Healy and Wilkins 1986a; Lin and Molnar, 1983). Thinning out weak vegetative shoots increased flower production (Heins and Wilkins, 1976). Possibly apical dominance was reduced and lateral rhizome growth was promoted because more light penetrated the canopy, thus increasing photosynthesis of young emerging shoots (Heins and Wilkins, 1979). It is believed (Healy et al., 1982) that exposure to a long-day regime and to high-intensity lighting may induce a new growth response dependent on enhanced photoassimilate production, which results in earlier flower production (Healy et al., 1982; Heins and Wilkins, 1979) and increased flower yield (Healy and Wilkins, 1986a; Lin and Monlar, 1983).

Unfortunately, in published reports, Alstroemeria plant density and LAI were not reported. In most greenhouse operations, LAI is frequently $>3.0$ to 4.5 , values that we used (Fig. 1). LAI can vary greatly during the growing cycle and is clearly influenced by

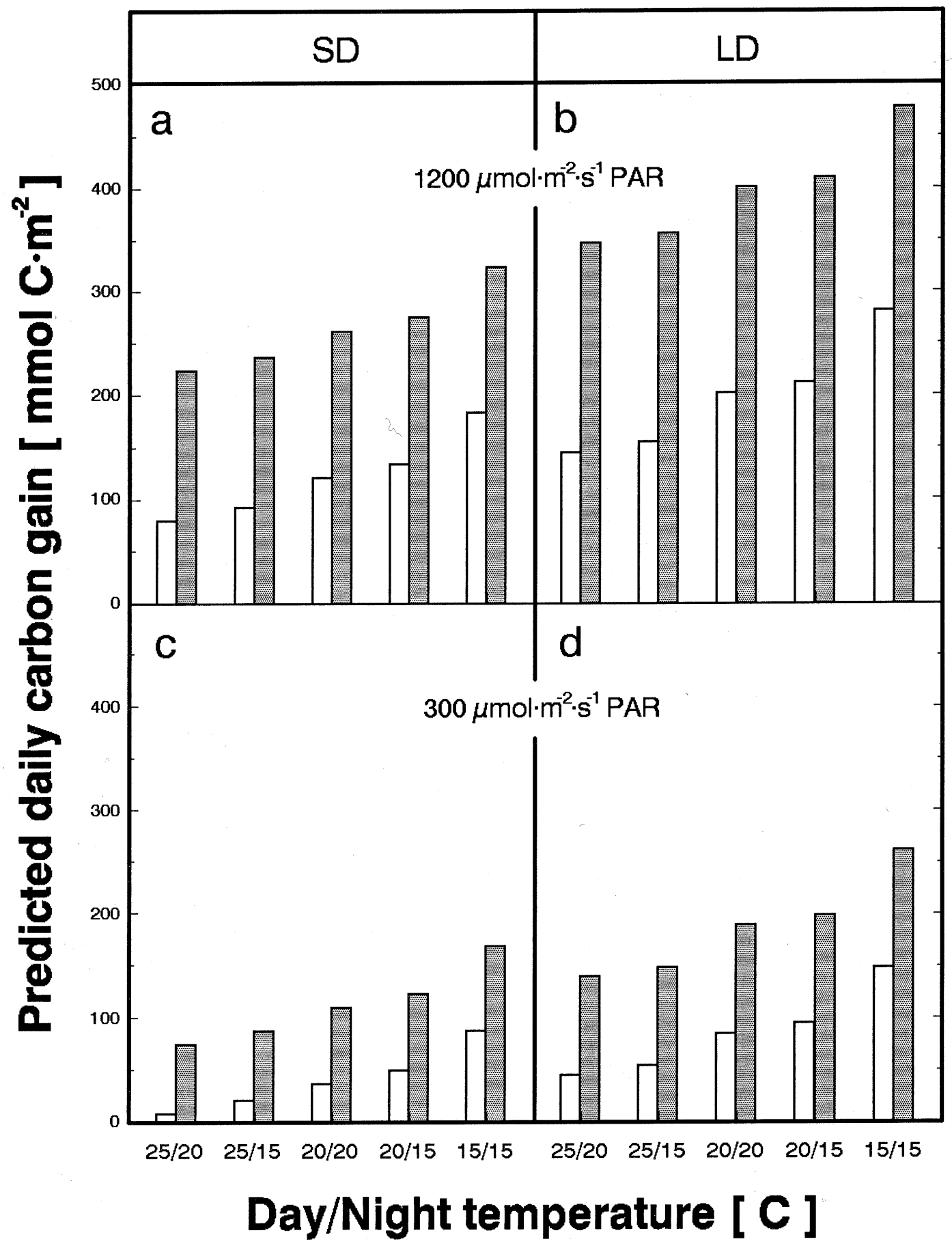

Fig. 6. Predicted daily $\mathrm{C}$ gain ( $\mathrm{mmol} \mathrm{C}$ fixed $/ \mathrm{m}^{2}$ leaf area) at several day and night temperature regimes. Daily $\mathrm{C}$ gain was predicted using the whole-plant net $\mathrm{C}$ exchange rate model of Eq.[1] and the Arrhenius whole-plant dark respiration model of Eq.[4] for short-day (SD) [10-h days and 14-h nights (a and c)] and long-day (LD) [14$\mathrm{h}$ days and 10-h nights (b and d)] case studies at irradiance levels of $1200(\mathbf{a}$ and $\mathbf{b})$ and $300(\mathbf{c}$ and $\mathbf{~ d}) \mu \mathrm{mol} \cdot \mathrm{m}^{-2} \cdot \mathrm{s}^{-1}$ photosynthetically active radiation (PAR) and at ambient (empty bars) and saturated (shaded bars) $\mathrm{CO}_{2}$. 
seasonal irradiance levels and thinning and harvesting flowering shoots. The leaves on the flowering shoot are usually smaller and fewer than those on vegetative shoots (Heins and Wilkins, 1979). Nevertheless, leaves on flowering and vegetative shoots have similar photosynthetic rates and respond similarly to changes in irradiance, $\mathrm{CO}_{2}$ concentration, and temperature (Leonardos, 1993).

Carbon dioxide. Our studies (Fig. 2) confirm a strong interaction between $\mathrm{CO}_{2}$ enrichment and irradiance. Alstroemeria has a $\mathrm{CO}_{2}$ compensation point of 40 to $50 \mu \mathrm{l} \cdot$ liter-1 $^{-1}$ typical of a $\mathrm{C}_{3}$ plant. Carbon dioxide enrichment (i.e., $900 \mu \mathrm{l} \mathrm{CO}_{2} /$ liter) in conjunction with supplementary HPS lighting when solar radiation fell below $375 \mu \mathrm{mol} \cdot \mathrm{m}^{-2} \cdot \mathrm{s}^{-1} \mathrm{PAR}$ increased production of Alstroemeria 'Mona Lisa' and 'Tiara' stems from 33 to $56 / \mathrm{m}^{2}$ and 47 to $74 / \mathrm{m}^{2}$, respectively (Euro-Floratech, 1992). The $\mathrm{CO}_{2}$ level $\left(900 \mu \mathrm{l} \cdot \mathrm{liter}^{-1}\right)$ used in the European studies is consistent with the $\mathrm{CO}_{2}$ levels (800 to $1000 \mu \mathrm{l} \cdot$ liter $^{-1}$ ) recommended for producing Alstroemeria in the greenhouse (Verboom, 1980). These observations and recommendations generally agree with the results of our data (Figs. 2 and 5 $\mathrm{a}-\mathrm{c})$ when irradiance levels are low. When the irradiance level was $1000 \mu \mathrm{mol} \cdot \mathrm{m}^{-2} \cdot \mathrm{s}^{-1}$ PAR or greater (Figs. 2 and $5 \mathrm{~d}-\mathrm{f}$ ), $\mathrm{CO}_{2}$ levels of 1400 to $2000 \mu \mathrm{l} \cdot$ liter $^{-1}$ were required to saturate the whole-plant photosynthetic response.

There is general agreement that $\mathrm{CO}_{2}$ enrichment is very beneficial under commercial situations, especially during winter when the greenhouses are tightly sealed and the $\mathrm{CO}_{2}$ concentration can decline considerably below ambient levels (Porter and Grodzinski, 1985). Data in Fig. 2 indicated that $\mathrm{CO}_{2}$ supplementation at subambient levels greatly improved $\mathrm{C}$ assimilation rates in Alstroemeria at the high and low irradiance levels tested. The response curves to different irradiance and $\mathrm{CO}_{2}$ levels (Fig. 5) provide insight into the parameters to be tested in more elaborate and costly, full-canopy greenhouse trials. Currently, except for generalizations about the long-term response of various $\mathrm{C}_{3}$ and $\mathrm{C}_{4}$ crops to $\mathrm{CO}_{2}$ enrichment (Bowes, 1993; Grodzinski, 1992), we do not have the data to predict exactly how a perennial $\mathrm{C}_{3}$ crop like Alstroemeria, given a certain planting density and being harvested and pruned continually, will behave after being exposed to long periods of $\mathrm{CO}_{2}$ enrichment. It remains to be determined how $\mathrm{CO}_{2}$ enrichment and possibly increased storage of photoassimilates resulting from long-term $\mathrm{CO}_{2}$ enrichment, even in warm summers, might affect the vernalization requirements for flowering in Alstroemeria.

There are several reasons why $\mathrm{CO}_{2}$ enrichment might be impractical in a commercial greenhouse during the summer, unless the greenhouse is equipped with an efficient cooling system such as evaporated cooling or shading. First, temperatures above 20C reduce Alstroemeria leaf and whole-plant photosynthesis. In fact, whole-plant photosynthesis was reduced above 15C (Fig. 4). Second, Alstroemeria requires cool temperatures to flower prolifically (Healy and Wilkins, 1982a). Third, excess solar radiation during the summer will cause the canopy temperature to rise, and the need for ventilation can negate the value of $\mathrm{CO}_{2}$ supplementation because of the loss of the added $\mathrm{CO}_{2}$ through ventilation.

Temperature during days and nights. As a simple case study addressing the question of the importance of temperature, consider first a situation in which the duration of the day is extended from 10 to $14 \mathrm{~h}$ of lighting for two sets of Alstroemeria plants that are grown in the same $20 \mathrm{C}$ day and $15 \mathrm{C}$ night temperature regime, the same high incident irradiance level of $1200 \mu \mathrm{mol} \cdot \mathrm{m}^{-2} \cdot \mathrm{s}^{-1} \mathrm{PAR}$, and the same (ambient) $\mathrm{CO}_{2}$ level (Fig. $6 \mathrm{a}$ and b). Based on the data in Figs. 3 and 5e, the long-day plants should accumulate $213 \mathrm{mmol}$ $\mathrm{C} / \mathrm{m}^{2}$ per day (Fig. $6 \mathrm{~b}$ ). During the 14 -h day, $239 \mathrm{mmol} \mathrm{C} / \mathrm{m}^{2}$ would be accumulated, while $26 \mathrm{mmol} \mathrm{C} / \mathrm{m}^{2}$ would be lost during respiration at night. In comparison, the short-day plants would have only grown at $63 \%$ of this rate, since only $134 \mathrm{mmol} \mathrm{C} / \mathrm{m}^{2}$ per day would have been available for future metabolism and growth, when one sums net day $\mathrm{C}$ gain for $10 \mathrm{~h}\left(171 \mathrm{mmol} \mathrm{C} / \mathrm{m}^{2}\right)$ with the night respiratory losses at $15 \mathrm{C}$ extended over the 14 -h dark period $\left(-37 \mathrm{mmol} \mathrm{C} / \mathrm{m}^{2}\right)$ (Fig. 6b). Although night $\mathrm{CO}_{2}$ losses through respiration for $4 \mathrm{~h}$ are significant $\left(-11 \mathrm{mmol} \mathrm{C} / \mathrm{m}^{2}\right)$, it is the absence of the $\mathrm{C}$ gained during a 4-h period of day photosynthesis $(68 \mathrm{mmol}$ $\mathrm{C} / \mathrm{m}^{2}$ ) that is numerically more important.

In a slightly different case study, if the night temperature for the 10 - and 14-h periods were $20 \mathrm{C}$ rather than $15 \mathrm{C}$ (Fig. $6 \mathrm{a}$ and b), the daily $\mathrm{C}$ accumulation would have been $203 \mathrm{mmol} \mathrm{C} / \mathrm{m}^{2}$ for the long-day plants instead of $213 \mathrm{mmol} \mathrm{C} / \mathrm{m}^{2}$ and $121 \mathrm{mmol} \mathrm{C} / \mathrm{m}^{2}$ for the short-day plants instead of $134 \mathrm{mmol} \mathrm{C} / \mathrm{m}^{2}$. An examination of comparable data sets with and without $\mathrm{CO}_{2}$ enrichment over a range of day and night temperature regimes shows a similar pattern in which night temperature differences of $5 \mathrm{C}$ are not as important to the final estimate of daily $\mathrm{C}$ gain as the day temperature or the duration of daylight (Fig. 6). In all cases, when comparing within a specific day and night temperature regime (20/15C), more growth would occur with longer light periods [i.e., long-day (14 h of light) vs. short-day ( $10 \mathrm{~h}$ of light)] and with $\mathrm{CO}_{2}$ enrichment. The effect of $\mathrm{CO}_{2}$ is totally consistent with the view that $\mathrm{CO}_{2}$ enrichment suppresses photorespiration (Bowes, 1993; Grodzinski, 1992).

The estimates of growth (biomass) in Fig. $6 \mathrm{c}$ and $\mathrm{d}$ forecast growth of Alstroemeria exposed to a partially overcast winter day when the irradiance level is definitely suboptimal for upper leaf and whole-plant photosynthesis (Fig. 1). The most striking feature of the data in Fig. $6 \mathrm{c}$ and $\mathrm{d}$ is the low values compared with those in Fig. 6 a and b. At low irradiance levels, short days, and warm aerial temperatures, plants would have very little extra $\mathrm{C}$ to sustain new flower growth. In fact, in the two cases when the temperature regimes were $25 \mathrm{C}$ day and $20 \mathrm{C}$ night and $20 \mathrm{C}$ day and night, daily $\mathrm{C}$ gain was very low, indicating that there may not be enough $\mathrm{CO}_{2}$ assimilated daily to maintain respiration in the plant.

Daily $C$ gain and flowering. Photoassimilates are required for flowering, but flowering initiation may not be controlled by current or instantaneous photosynthesis rates. Healy and Wilkins, (1982a) reported that flowering in Alstroemeria 'Regina' was hastened by forcing the plants at $21 \mathrm{C}$ day and $18 \mathrm{C}$ night vs. $13 \mathrm{C}$ day and $13 \mathrm{C}$ night air temperatures. However, the $21 \mathrm{C}$ day and $18 \mathrm{C}$ night forcing air temperatures reduced flower production compared to $13 \mathrm{C}$ day and $13 \mathrm{C}$ night. In addition, a decrease in air temperature by a few degrees only (mean days and nights of 20 and $14 \mathrm{C}$ and 20 and $13 \mathrm{C}$ vs. 22 and $13 \mathrm{C}$ and 24 and 14C) resulted in increased flower production of Alstroemeria 'Atlas' and 'Monika' (Keil-Gunderson et al., 1989).

Although HPS supplementary lighting alone increased flower production in Alstroemeria, it was more effective when used with soil cooling (Blom and Piott, 1991; Lin, 1984,1985). Lin (1985) reported that HPS supplementary lighting had little effect on flower production when the benches on which the plant were growing were not cooled. In addition, Healy and Wilkins (1986b) concluded that flowering in Alstroemeria 'Regina' is primarily controlled by soil temperature (13 or 21C), regardless of air temperature (13 or $21 \mathrm{C}$ ) or photoperiod. However, a higher percentage of flowering shoots was associated with higher root and rhizome dry weights, which were promoted when soil and air temperatures were $13 \mathrm{C}$ and the night period was interrupted. Wilkins et al. (1980) also reported that the optimum temperature for growth of storage roots was at a low temperature of $15 \mathrm{C}$ and that, at 20 and $25 \mathrm{C}$, root growth was fibrous with only a few enlarged storage roots, possibly due to high respiration rates. It has 
been proposed (Healy and Wilkins, 1982b; Wilkins et al., 1980) that specific plant growth substances such as gibberillins may begin to accumulate in the plants and become conjugated with the stored $\mathrm{C}$. Once a critical pool of metabolites and growth regulators has accumulated, flowering can occur. Future experiments must be directed at evaluating specifically how root zone $\mathrm{C}$ status controls flowering in a variety of greenhouse conditions.

Although the experiments conducted in this study were on Alstroemeria 'Jacqueline', the photosynthetic sensitivity to high temperatures was also evident for two other cultivars measured'Rosario' and 'Carmen' (data not shown). The importance of irradiance will dominate any photosynthesis and growth model, but whole-plant and canopy experiments with other cultivars and other crop densities need to be tested. Examining the photosynthetic response to temperature of cultivars that flower year-round may provide insight into the link between the temperature dependence of photosynthesis and that of flower production.

\section{Literature Cited}

Aker, S. and W. Healy. 1990. Shoot removal affects Alstroemeria development. HortScience 25:1110. (Abstr.)

Blom, T.J. and B.D Piott. 1990. Constant soil temperature influences flowering of alstroemerias. HortScience 25:189-191.

Blom, T.J. and B.D Piott. 1991. Annual summary of horticultural projects. Alstroemeria HPS lighting and cooling. HRIO Vineland Sta. Floret Bul. Bowes, G. 1993. Facing the inevitable: Plants and increasing atmospheric $\mathrm{CO}_{2}$. Annu. Rev. Plant Physiol. 44:309-332.

Bridgen, M.P. and J. Bartok. 1990. Evaluation of a growing medium cooling system and its effects on the flowering of Alstroemeria. HortScience 25:1592-1594.

Dutton, R.G., J. Jiao, M.J. Tsujita, and B. Grodzinski. 1988. Whole plant $\mathrm{CO}_{2}$ exchange measurements for nondestructive estimation of growth. Plant Physiol. 86:355-358.

Enoch, H.Z. and J.M. Sacks. 1978. An empirical model of $\mathrm{CO}_{2}$ exchange of a $\mathrm{C}_{3}$ plant in relation to light, $\mathrm{CO}_{2}$ concentration and temperature. Photosynthetica 12:150-157.

Euro-Floratech. 1992. HPS light extends alstroemeria production. EuroFloratech Bul., Nov. 1992.

Graper, D. and W. Healy. 1990. Alstroemeria carbohydrate partitioning. HortScience 25:1070. (Abstr.)

Grodzinski, B. 1992. Plant nutrition and growth regulation by $\mathrm{CO}_{2}$ enrichment. BioScience 42:517-525.

Healy, W.E. and H.F. Wilkins. 1982a. The interaction of temperature on flowering of Alstroemeria 'Regina'. J. Amer. Soc. Hort. Sci. 107:242251.

Healy, W.E. and H.F. Wilkins. 1982b. Responses of Alstroemeria 'Regina' to temperature treatments prior to flower-inducing temperatures. Scientia Hort. 17:383-390.

Healy, W.E. and H.F. Wilkins. 1986a. Influence of light treatments before and after induction treatment on flowering of Alstroemeria 'Regina'. HortScience 21:1390-1392.

Healy, W.E. and H.F. Wilkins. 1986b. The independent relationship between rhizome temperatures and shoot temperatures for floral initiation and cut flower production of Alstroemeria 'Regina'. J. Amer. Soc. Hort. Sci. 111:94-97.

Healy, W.E., H.F. Wilkins, and M. Celusta. 1982. The role of light quality, photoperiod, and high-intensity supplemental lighting on flowering of Alstroemeria 'Regina'. J. Amer. Soc. Hort. Sci. 107:1046-1049.

Heins, R.D. and H.F. Wilkins. 1976. Alstroemeria cultural research 1975-76. Univ. of Minnesota. The influence of night interruption with incandescent light and shoot-pruning techniques. Flor. Rev. 159(124):34-35, 80-81.

Heins, R.D. and H.F. Wilkins. 1979. Effect of soil temperature and photoperiod on vegetative and reproductive growth of Alstroemeria 'Regina'. J. Amer. Soc. Hort. Sci. 104:359-365.

Jiao, J., M.J. Tsujita, and B. Grodzinski. 1991a. Optimizing aerial environments for greenhouse rose production utilizing whole-plant net $\mathrm{CO}_{2}$ exchange data. Can. J. Plant Sci. 71:253-361.

Jiao, J., M.J. Tsujita, and B. Grodzinski. 1991b. Influence of temperature on net $\mathrm{CO}_{2}$ exchange in roses. Can. J. Plant Sci. 71:235-243.

Jiao, J., M.J. Tsujita, and B. Grodzinski. 1991c. Influence of radiation and $\mathrm{CO}_{2}$ enrichment on whole plant net $\mathrm{CO}_{2}$ exchange in roses. Can. J. Plant Sci. 71:244-252.

Johnson, I.R. and J.H.M. Thornley. 1985. Temperature dependence of plant and crop processes. Ann. Bot. 55:1-24.

Keil-Gunderson, L.S., K.L. Goldsberry, and P.L. Chapman. 1989. Air and substrate temperatures for 'Atlas' and 'Monica' alstroemeria. HortScience 24:613-616.

Leonardos, E.D. 1993. Environmental effects on net carbon exchange in Alstroemeria. MS thesis. Univ. of Guelph, Ont., Canada.

Leonardos, E.D., M.J. Tsujita, B. Grodzinski, and T.J. Blom. 1992a. A comparison of leaf and whole-plant net photosynthesis in Alstroemeria. HortScience 27:576. (Abstr.)

Leonardos, E.D., M.J. Tsujita, B. Grodzinski, and T.J. Blom. 1992b. The effect of temperature on carbon gain in Alstroemeria. HortScience 27:649. (Abstr.)

Lin, W.C. 1984. The effect of soil cooling and high intensity supplementary lighting on flowering of Alstroemeria 'Regina'. HortScience 19:515516.

Lin, W.C. 1985. Influence of soil cooling and high intensity lighting on the growth and flowering of Alstroemeria 'Regina'. HortScience 20:378380.

Lin, W.C. and J.M. Molnar. 1983. Effect of photoperiod and high intensity supplementary lighting on flowering of Alstroemeria 'Orchid' and 'Regina'. J. Amer. Soc. Hort. Sci. 108:914-917.

McCree, K.J. 1986. Measuring the whole-plant daily carbon balance. Photosynthetica 20:82-93.

Osborne, B.A. and M.K. Garrett. 1983. Quantum yields for $\mathrm{CO}_{2}$ uptake in some diploid and tetraploid plant species. Plant Cell Environ. 6:135144.

Pappas, T. and C.A. Mitchell. 1985. Influence of seismic stress on photosynthetic productivity, gas exchange, and leaf diffusive resistance of Glycine max (L.) Merrill cv Wells II. Plant Physiol. 79:285-289.

Pickard, W.F. and P.E.H. Minchin. 1990. The transient inhibition of phloem translocation in Phaseolus vulgaris by abrupt temperature drops, vibration, and electric shock. J. Expt. Bot. 41(323):1361-1369.

Porter, M.A. and B. Grodzinski. 1985. CO enrichment of protected crops. Hort. Rev. 7:345-398.

Proctor, J.T.A., J.M. Bodnar, W.J. Blackburn, and R.L. Watson. 1982. Analysis of the effects of the spotted tentiform leafminer (Phyllonorycter blancardella) on the photosynthetic characteristics of apple leaves. Can. J. Bot. 60:2734-2740.

SAS Institute. 1988. SAS/STAT, GRAPH. User's guide for personal computers. release 6.03. SAS Inst., Cary, N.C.

Verboom, H. 1980. Alstroemerias and some other flower crops for the future. Scientia Hort. 31:33-42.

Wilkins, H.F., W.E. Healy, and T.L. Gilbertson Ferriss. 1980. Comparing and contrasting the control of flowering in Alstroemeria 'Regina', Freesia $\times$ hybrida and Lilium longiflorum, p. 51-63 In: C. Brichell, D.F. Cultler, and M. Gregory (eds.). Petaloid monocotyledons, horticulture and botanical research. Academic Press, London.

Woodrow, T., R.G. Thompson, and B. Grodzinski. 1988. Effects of ethylene on photosynthesis and partitioning in tomato, Lycopersicon esculentum Mill. J. Expt. Bot. 39:667-684. 